\title{
Tekniskkulturarv.dk - en god historie
}

Unikke bøger og billeder om dansk industri og teknik er nu blevet digitaliseret og gjort tilgængelige - primært materiale, der ikke tidligere er indscannet af andre biblioteker.
Af Peter Hald

bibliotekar, cand.scient.bibl

phal@dtu.dk

Beatrice Raarup,

DTU Bibliotek bibliotekar DB

berat@dtu.dk

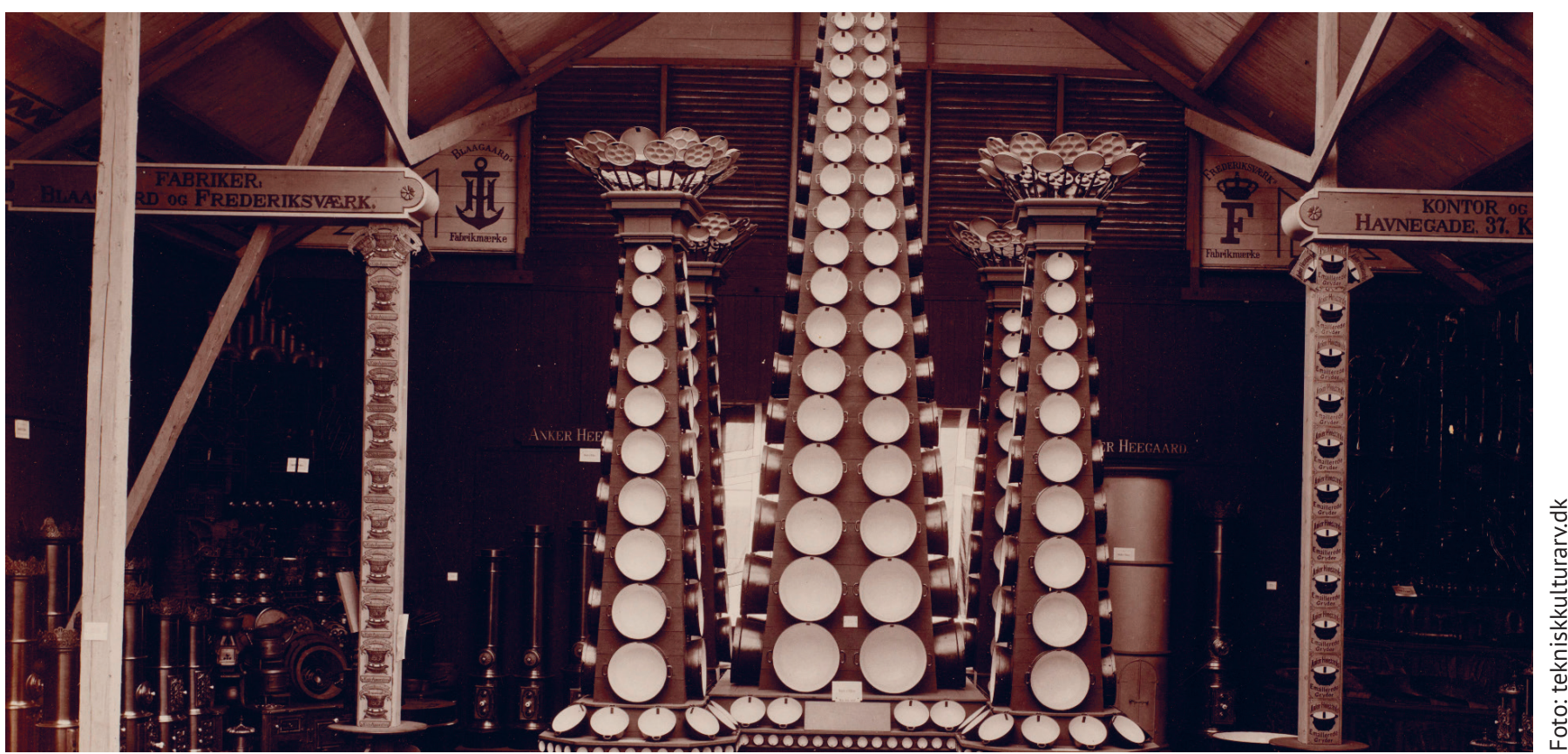

Kan De lide emalje? Her billede af kakkelovne og emaljerede gryder m.m. udstillet på Den Nordiske Industri-, Landbrugs- og Kunstudstilling 1888. Foto: Juncker Jensen.

I kælderen under DTU står en enestående bogsamling, som giver et unikt indblik i skabelsen af det moderne Danmark og det samfund, vi har i dag.

DTU Bibliotek blev oprettet i 1942 ved en sammenlægning af Teknisk Bibliotek og Industriforeningens Bibliotek, der tilsammen havde cirka 30.000 værker stående. Disse bøger har i mange år levet en hengemt tilværelse i et lukket magasin i kælderen under DTU, og det har længe været et stort ønske for DTU Bibliotek at få digitaliseret dele af samlingen for at øge tilgængeligheden og kendskabet til denne. Dette er nu gjort på www.tekniskkulturarv.dk

Sitet består af mere end 800 digitaliserede bøger, som bredt dækker de forskellige emneområder i samlingen.
Det er blot en brøkdel af de mere end 30.000 titler, samlingen består af. Derfor var det også vigtigt for projektet at synliggøre de mere end 130.000 katalogkort, samt Industriforeningens katalog fra 1923. Det rummer titler primært fra starten af 1800-tallet og frem til 1967, hvor DTU Bibliotek begyndte at digitalisere bogposter. Til dette formål var det også nødvendigt at lave en database, hvor disse katalogkort blev omdannet til metadata på bøgerne.

Dette blev muliggjort, da Aage og Johanne Louis-Hansens Fond, Martha og Paul Kern-Jespersens Fond og Otto Mønsteds Fond alle skød penge ind i projektet. En projektgruppe blev nedsat med deltagere fra DTU Bibliotek og Teknologihistorie DTU og var en blanding af bibliotekarer, udviklere og en historiker. Der blev desuden lavet en aftale med virksomheden Scanning.dk om den omfattende indscanning af katalogkort og bøger, da det ikke var en opgave, DTU Bibliotek selv kunne løfte.

\section{Hvem kan få glæde af sitet?}

Fra starten var ønsket at skabe et site for både historikere, fagnørder og gymnasieelever, der tilgodeså de behov, disse brugergrupper måtte have.

Undervisere og elever ved de gymnasiale uddannelser er en vigtig målgruppe for sitet. Derfor valgte gruppen at lave en sektion bestående af forskellige temaer med bøger og billeder fra samlingen, som kan være relevante til undervisningsbrug. 
Der er timers godt tidsfordriv i at kigge på bøger om dansk teknologihistorie ikke mindst om de talrige projekter, der aldrig blev til noget. Her betænkning om

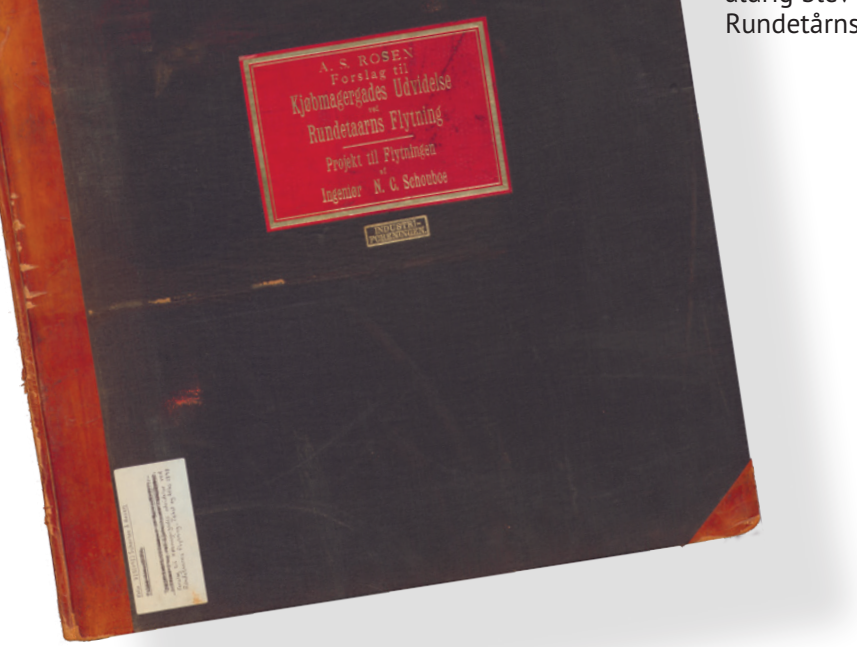

9

Der er timers godt tidsfordriv i at kigge på bøger om dansk teknologihistorie

Det er fx temaet om forurening, der også var et problem i 1800-tallet. Her er der flere titler, som kan benyttes til at belyse forurening $i$ et historisk perspektiv.

Faghistorikeren har mulighed for at dykke ned i selve samlingen og finde kilder, der kan belyse de dele af teknologi- og industrihistorien, han eller hun nu måtte beskæftige sig med. Veteranbilentusiasten kan fx kigge nærmere på bogen 100 Vink og Raad for Automobilister anno 1920.

\section{Også stor fotosamling fra 1888}

Projektgruppen har valgt primært at digitalisere bøger, der ikke tidligere er indscannet af andre biblioteker.
Eksempelvis betyder det, at værker af H.C. Ørsted, grundlægger af Polyteknisk Læreanstalt (nu DTU), ikke er omfattet af dette projekt, da de tidligere er digitaliseret og tilgængeliggjort af Det Kongelige Bibliotek.

Endvidere er en samling fotografier fra Den Nordiske Industri-, Landbrugs-og Kunstudstilling i 1888 også blevet tilgængeliggjort. Udstillingen var en vigtig begivenhed, som satte streg under, hvor langt Danmark var kommet industrielt allerede dengang. Der har længe været interesse for denne billedsamling, men det har ikke tidligere været muligt at tilgå billederne uden først at lave en aftale med biblioteket.

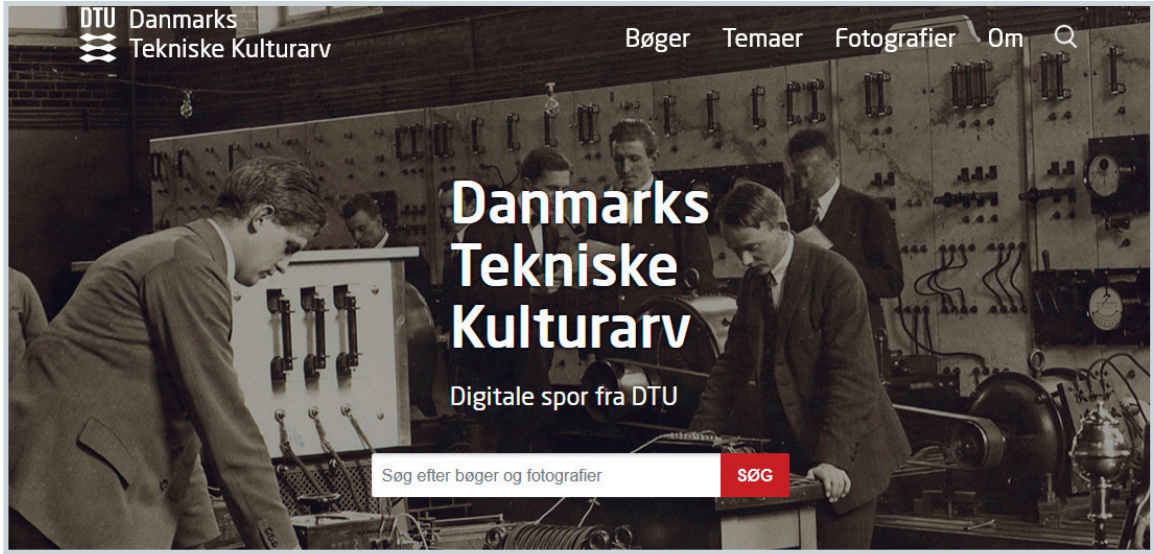

Få et unikt indblik i baggrunden for det moderne samfund med masser af teknologi, industri og bekvemmeligheder som varmt vand i hanen, jernbaner og elektricitet.

Søg i DTU's samling af historisk-tekniske bøger, se historiske fotografier eller dyk ned i et særligt tema.
Teknologihistorie DTU

Med sitet tekniskkulturarv.dk er dørene slået op til et fascinerende, hengemt univers.
Bøgerne er tilgængelige som pdf-filer og i ocr-tekst, der kan læses på sitet eller downloades til egen computer. Da alle indscannede bøger er fra før 1920, er de som udgangspunkt fri af ophavsretten og kan frit benyttes. Alle bøger har fået en CC-BY-SA 4.0 licens.

Vi har oplevet stor interesse for projektet og håber på sigt at kunne udvide mængden af både scannede bøger og billeder yderligere. Der gemmer sig nemlig stadigvæk masser af spændende værker i bibliotekets kælder, som fortjener at se dagens lys.

\section{Peter Hald og Beatrice Raarup}

har været del af projektgruppen

og er kontaktpersoner på

www.tekniskkulturarv.dk, DTU Bibliotek. 